\title{
Results of Advanced Battery Technology Evaluations for Electric Vehicle Applications
}

\author{
W. H. Deluca, K. R. Gillie, J. E. Kulaga, J. A. Smaga, \\ A. F. Tummillo, and C. E. Webster
}

\author{
Chemical Technology Division \\ Electrochemical Technology Program \\ Argonne National Laboratory \\ Argonne, IL 60439
}

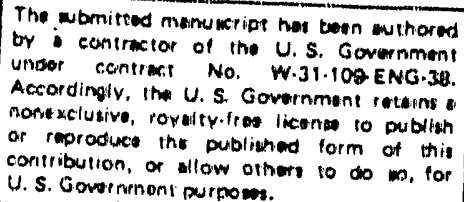

\section{SAE 1992 Future Transportation Technology Conference Costa Mesa, CA August 10 - 13, 1992}

\author{
DISCLAIMER
}

\begin{abstract}
This report was prepared as an account of work sponsored by an agency of the United States Government. Neither the United States Government nor any agency thereof, nor any of theit employees, makes any warranty express or implied, or assumes any legal liability of responsibility for the accuracy, completeness, or usefulness of any information, apparatus, product, or broce ence herein to any specific commercial produch, process, or service by trade name, trademark, chen hereinto any or imply its endorsement. recommendation, or favoring by the United States Government of an: agency thereor. The views ant of ef reflect those of the United Stales Government of any ageney thereof.
\end{abstract}




\section{ABSTRACT}

Advanced battery technology evaluations are performed under simulated electric-vehicle operating conditions at the Analysis \& Diagnostic Laboratory (ADL) of Argonne National Laboratory. The ADL results provide insight into those factors that limit battery performance and 1140 . The ADL. facilities include a test laboratory to conduct bactery experimental evaluations under simulated application conditions and a post-test analysis laboratory to determine, in a protected atrnosphere if needed, component compositional changes and failure mechanisms. This paper summarizes the performance characterizations and life evaluations conducted during 1991 - 1992 on both single cells and multi-cell modules that encompass eight battery technologies [ $\mathrm{Na} / \mathrm{S}, \mathrm{LI} / \mathrm{MS}$ ( $M=$ motal), $\mathrm{Ni} / \mathrm{MH}, \mathrm{Ni} / \mathrm{Cd}, \mathrm{Ni} / \mathrm{Zn}, \mathrm{Ni} / \mathrm{Fe}, \mathrm{Zn} / \mathrm{Br}$, and $\mathrm{Pb}$-acid]. These evaluations were performed for the Department of Energy, Office of Transportation Technologies, Electric and Hybrid Propulsion Division, and the Electric Power Research Institute. The ADL provides a common basis for battery performance characterization and life evaluations with unbiased application of tests and analyses. The results help identify the most-promising R\&D approaches for overcoming battery limitations, and provicle battery users, developers, and program managers with a measure of the progress being made in battery R\&D programs, a comparison of battery technologies, and basic data for modeling.

\section{INTRODUCTION}

The Analysis \& Diagnostic Laboratory (ADL). established at Argonne National Laboratory (ANL) by the Department of Energy (DOE) in 1976, is a facility for studying advanced battery systems. It includes (1) a versatile computer-operated test laboratory to conduct battery evaluations under simulated application conditions and (2) a post-test analysis laboratory to determine, in a protected atmosphere if needed, component compositional changes and failuie mechanisms. The ADL evaluates battery systems using standardized tests and analyses on a common, unbiased basis. The experimental data and their analyses, in combination with post-test examinations of these advanced battery systems, help identify factors that limit system performance and llfe and the most. promising R\&D approaches for overcoming these limitations.

The ADL facilities have been used to evaluate battery systems of various types and sizes for the DOE, Electric Power Research Institute (EPRI), and private industry. Over 3000 cells, ranging from individual 4-Wh cells to 360 -cell, $22-\mathrm{kWh}$ batteries and representing 12 battery lechnologies from over 18 developers, have undergone performance characterizations and life evaluations for electric vehicle (EV) propulsion, utility load-leveling, and standby power applications. The results of evaluations conducted during 1990 and the first quarter of 1991 were reported in August 1991. ${ }^{1}$

Firom January 1991 to May 1992. EV battery evaluations were performed for the DOE Office of Transportation Technologies, Electric and Hybrid Propulsion Division (OTT/EHP), and the EPRI Transportation Program. Performance characterizations and/or life evaluations were conducted on eight battery technolugies [Na/S. 
Li/MS ( $\mathrm{M}=$ metal), $\mathrm{Ni} / \mathrm{MH}, \mathrm{Ni} / \mathrm{Cd}, \mathrm{Ni} / \mathrm{Zn}, \mathrm{Ni} / \mathrm{Fe}$, $\mathrm{Zn} / \mathrm{Br}$, and $\mathrm{Pb}$-acid]. The evaluations performed and results obtained are discussed below.

\section{STANDARDIZED AND SPECIAL TESTS}

Standardized tests have been developed to characterize the performance of batteries for EV propulsion applications. All of the standardized performance tests are conducied on mature technologies, but only subsets of these tests are used on research cells because a shorter life and/or limited performance is anticipated. Performance characterization includes the measurernent of:

1. raied capacity under manufacturer specified operating conditions

2. capacity vs. constant current $(\mathrm{Cl})$ and constant power (CP)

3. available peak power vs. depth-of-discharge (DOD) for acceleration capability

4. self-discharge losses vs. stand time

5. sustained hill-climbing capability

6. effect of partial discharge on available $100 \%$ DOD capacity

7. projected ranges for various vehicles and driving schedules

Life cycle tests are typically conducted with 80 or $100 \%$ capacity discharges using a simulated driving power profile. Life evaluations with $100 \%$ DOD cycles are continued until the energy capacity declines to $80 \%$ of the initial or rated value, whichever was less. Life evaluations with $80 \%$ DOD cycles are continued until the battery can no longer provide the $80 \%$ DOD energy before reaching its $100 \%$ DOD condition. During the life evaluation, reference cycles are conducted at $\sim 25$ cycle intervals to establish a baseline $3 \cdot \mathrm{h}$ rate capacity history and at -50 -cycle intervals to determine the effects of age on battery resistance. IR-tree voltage, and peak power. The driving profiles used in these performance characterizations and life evaluations include:

1. Simplified Federal Urban Driving Schedule (SFUDS) for the improved van of the DualSystem Electric Propuision (DSEP)Program (SFUDS/IDSEP)

2. SAE J227aC urban driving schedule for the General Motors G-Van (J227aC/G-Van)
3. SAE J227aC urban driving schedule for the Chrysler TEVan (J227aC/TEVan)

4. SAE J227aD urban driving schedule for the improved ETV-1 vehicle (J227aD/IETV-1)

The power profile for each of the above driving schedules was obtained from a vehicle test laboratory and is based on data either recorded during $E v$ road tests or generated by a computer EV-simulation program. Each power profile was normalized to the weight of the battery used to propel the vehicle. To determine the power levels that must be imposed on a single cell or module for driving profile discharges, the mass of the cell or module is multiplied by the specific power profile. With this methodology, the battery mass originally installed in the vehicle remains constant. For hightemperature cells and modules, a weight burden is added to the measured weight to include a share of the weight for a thermal enclosure, heaters, interconnectors, etc. In some cases, this burden is $>85 \%$ of the cell weight. Table 1 lists the general characteristics of each power profile.

A computer-control and data-acquisition system is used to cycle and monitor the cells and modules during testing at the ADL. The signals measured and recorded include inodule voltage and current, voltage and temperature of each cell (if available), and ambient temperature of the laboratory test enclosure. When possible, battery temperatures are measured within the cell cases; otherwise, a surface measurement is made on the cell case. The energy (Wh) and coulombic charge (Ah) transferred during each charge and discharge period are calculated by the computer from the voltage and current signals of the cell or module. All the signals are quantified, computations performed, and data recorded at one-second intervals for driving profile discharges and approximate one-minute intervals for $\mathrm{Cl}$ and $\mathrm{CP}$ discharges. Cell and module internal resistance, IR-free voltage, and peak power vs. DOD data are derived from the measured values of cell and module voltage and current during driving profile discharges. During life testing, the effect of age on these parameters is evaluated.

\section{TEST RESULTS}

Table 2 lists the general specifications and best performance (for the specified test conditions) of each EV battery technology evaluated at the ADL from January 9991 to May 1992 . Plots of specific

$$
\frac{\text { W. H. Deluca }}{\text { Author ivame }} \quad \frac{.2}{\text { Page }}
$$


energy and specific peak power for each technology are given in Figs. 1 anu 2 , respectively. The values of specific energies were measured using C.P discharges to $100 \%$ DOD. The values of specific peak power were derived from driving profile discharge data and are plotted as a function of DOD based on available energy for the average power discharge rate. Results of the standardized hill-climb capability test are given in Fig. 3 . The time that each battery is capable of propelling an electric car (IETV-1) up a hill (7\% grade) at $30 \mathrm{mph}$ $(45 \mathrm{~W} / \mathrm{kg}$ load) is plotted as a function of DOD achieved at a $15 \mathrm{~W} / \mathrm{kg}$ rate. Selested results of the extended open-circuit stand test, plotted in Fig. 4, show the effects of self-discharge vs. time for each of the battery technologies exarnined. The data for the high-temperature systerns ( $\mathrm{Na} / \mathrm{S}$ and $\mathrm{Li} / \mathrm{MS}$ ) do not reflect enclosure thermal iosses. Selected results for each technology are discussed below.

SODIUM/SULFUR TECHNOLOGY . TWO Na/S systems were evaluated: one was a one-half sized (22-kWh) Na/S EV battery fabricated by ASEA Brown Boveri $(A B B)$, and the other was an $8-V$ $\mathrm{Na} S \mathrm{~S}$ module from Chloride Silent Power Ltd. (CSPL). The 240-Ah, 90-V battery of $A B B$ was shipped to ANL at operating tempera! ure $\left(310^{\circ} \mathrm{C}\right)$ with thermal and safety management systems in May 1990 . It contained 360 cells (30-Ah rating) configured into three series-connected banks. Each bank contained eight parallel-connected strings of 15 series-connected cells. Performance characterization tests were completed, and life testing initiated in October 1990. This battery systern exhibited the highest specific energy (and provided the greatest simulated vehicle driving range) of any battery technology examined to date. Because the internal ${ }^{2} R$ heat losses were low, the cooling system was not used during driving profile discharges. The enclosure heat loss at a battery temperature of $-310^{\circ} \mathrm{C}$ was $176 \mathrm{~W}$. This heat loss would cause a capacity decline of about $0.8 \% / \mathrm{h}$ if the battery were used to power its heaters (selfdischarge loss). Life testing was terminated in August 1991 because the battery operating temperature could not be maintained at $310^{\circ} \mathrm{C}$. The module had completed 589 cycles and retained $-81 \%$ of its initial 238 -Ah capacity when the temperature started to decline. After 592 cycles, the battery was returned to $A B B$ for post-test analysis. A cursory inspection when the battery was opened revealed that three cells had failed, and a hole existed in the thermal enclosure wall (below one of the failed cells) that anpeared to be the result of sodium-polysulfide corrosion. Researchers at $A B B$ are conducting a more detailed post-test analysis and will furnish a report of their findings.

The 8-V Na/S module from CSPL was under test from June 1990 to March 1992. The module contained 120 cells (10-Ah each) configured into 30 parallel-connected strings of four seriesconnected cells. This 300-An module was of the same design and assembly as those (24 seriesconnected modules) in the battery system for the ETX-II vehicle (a light-duty van based on the Ford Aerostar). Life lesting with SFUDS discharges to $100 \%$ DOD was started in October 1990 after completion of the performance characterization tests $(\sim 120$ cycles accrued). Test results indicate that the performance of this module is similar to that of the ABB battery. However, the CSPL module has a higher internal resistance and, therefore, cannot achieve as high a peak power. End-of-life ( $<80 \%$ of initial 2084 -Wh SFUDS discharge energy) occurred at cycle 795 , but testing was continued to acquire additional statistics for cell failure analyses. Testing was halted in March 1992 (21 months and 973 cycles at operating remperature) when the SFUDS discharge energy decreased to $<75 \%$ of its initial level. There was a significant drop in module capacity between 450 and 550 cycles of operation, which reflected the loss of four 4-cell strings ( 40-Ah loss). Module resistance increased by $-20 \%$, which also indicated the loss of four strings in the 30-string battery. Due to the increase in module resistance with life, the peak power declined from an initial 94 $\mathrm{W} / \mathrm{kg}$ to only $68 \mathrm{~W} / \mathrm{kg}$ at the end of testing $(50 \%$ DOD). After 973 cycles, the module retained $-79 \%$ of its initial 292 -Ah capacity (3-h rate) and $-73 \%$ of its initial 2084-Wh SFUDS discharge energy $(100 \%$ DOD). Between cycles 934 and 973 , module resistance at end-of-discharge suddenly increased from 7.2 to $7.5 \mathrm{~m} \Omega$. This $4 \%$ increase in resistance in less than 40 cycles reflects the loss of another 4cell string. The module was returned to CSPL (England) for post-test analyses. While the module was prepareu for shipment, a visual inspection revealed that at least two cells had breached their containers.

LITHIUM/METAL SULFIDE TECHNOLOGY Two Li/MS cells were delivered to ANL for baseline performance testing under an R\&D development contract with SAFT of America, Inc. (Cockeysville, MD). The first cell was placed on test in May 1991. At an operating temperature of $470^{\circ} \mathrm{C}$, a capacity' 
of 182.5 Ah was obtained at the 3-h rate. This was $-14 \%$ below the capacity measured at SAFT using an operating temperature of $485^{\circ} \mathrm{C}$. At the ADL, the operating temperature was raised in $5^{\circ} \mathrm{C}$ steps to $485^{\circ} \mathrm{C}$ to observe the effect on cell capacity. The results showe that cell capacity, internal resistance, IR-fre : voltage, and peak power capability were sensitive to temperature. After completing 30 cycles of operation, the cell still retained $98 \%$ of its initial capacity, but was removed from test to undergo post-test analysis.

The second cell was placed on test in July 1991. Based on preliminary test results, the cell was operated at a temperature of $465^{\circ} \mathrm{C}$. Because the clamping arrangement used in the test fixture for this cell was modified to allow more compression on the electrode face, this cell performed much better than the first. Performance characterization tests were completed, and life lests started in December 1991 after 120 cycles were accrued. After completing 158 cycles, testing was suspended, and the cell was cooled to ambient temperature for the December holiday shutdown period (two weeks). In January 1992, the cell was heated to $465^{\circ} \mathrm{C}$ and testing resumed. A capacity of 198 Ah (239 Wh) was obtained on the first discharge. This was an improvement over that ot itained before the holiday shutdown (cycle 155). However, on the second discharge, a capacity of only 174 Ah was obtained, and the cell voltage declined to $0.8 \mathrm{~V}$ during a 1 -h open-circuit after discharge (OCAD) period (a voltage of $>1.2 \mathrm{~V}$ is expected). A $120 \%$ charge return was applied on the subsequent charge, but the cell voltage never increased to the CV chiarge level of $1.5 \mathrm{~V}$. The decline in voltage during the (OCAD) period and the inability to reach the CV charge level with $120 \%$ charge return indicate a high internal selt-discharge rate. A capacity of $174 \mathrm{Ah}$ (208 Wh) was obtained on the last discharge (cycle 163). Testing was suspended at that time, and no further analyses were performed on this cell.

ZINC/BROMINE TECHNOLOGY - A 5-kWh, 48$V Z n / B r$ module $(Z B B-5 / 48)$ from the Studiengesellschaft fur Energiespeicher und Antriebssysteme (SEA) (Research Group for Energy Storage and Propulsion Systems, Austria) underwent $E V$ performance and life testing from November 1989 to June 1991. Performance characterization tests showed that the SEA battery has good specific energy $(-79 \mathrm{Wh} / \mathrm{kg}$ at $3-\mathrm{h}$ rate). but low power capability $(-53 \mathrm{~W} / \mathrm{kg}$ at $50 \% \mathrm{DOD})$. The low power is due to a high internal battery resistance. The battery also exhibited a high self. discharge loss ( $-20 \%$ loss in $24 \mathrm{~h})$ when its electrolyte pumping motors remain energized. This loss is significantly reduced when pump operation is halted during extended open-circuit times. Life testing with SFUDS discharges to $100 \%$ DOD was started in March 1990 after performance testing ( 130 cycles accrued). Because of the high module resistance, a peak discharge current limit (150 A) had to be imposed with SFUDS discharges to avoid reaching the discharge cut-off voltage (DCOV) on the first $79 \mathrm{~W} / \mathrm{kg}$ profile power peak. With a 150 A current limit, a maximum power of $-67 \mathrm{~W} / \mathrm{kg}$ was obtained at the start of the discharge, and $50 \mathrm{~W} / \mathrm{kg}$ was attained at the $27 . \mathrm{V}$ DCOV. The module reached end-of-life ( $>20 \%$ loss of initial capacity) after 334 cycles, and was returned to SEA for post-test analyses.

NICKEL/METAL HYDRIDE CELLS Performance and life tests were conducted on $\mathrm{Ni} / \mathrm{MH}$ cells marlufactured by Ovonics Battery Company (Troy, MI) to determine the suitability of this technology for EV applications. Previously tested in 1990, C-size (3.5-Ah rating) cells exhibited good performance characteristics, but the cycle life of four cells $\{33,238,289$, and 333 cycles) was less than expected ( 500 cycles). Two extended $\mathrm{C}$-size cells $(\sim 4.5 \mathrm{Ah})$ were evaluated in mid-1991. The specific energy of these cells was slightly higher than that of the smaller $\mathrm{C}$-cells, but the cycle life was still less than expected. These early cells exhibited a high self-discharge loss (14 to $38 \%$ loss in $24 \mathrm{~h}$ and 45 to $70 \%$ loss in 7 days). Ovonics subsequently modified component materials and reduced the seif-discharge loss to 15 to $20 \%$ in 7 days.

Performance and life tests were also conducted on two $\mathrm{Ni} / \mathrm{MH} \mathrm{H}$-cells (25-Ah rating), which represented an intermediate step in an Ovonics program to fabricate and develop large, full-size EV battery cells. The two cells were delivered to ANL in June 1991. Performance characterization tests were completed, and life evaluation started in November 1991. Life tests are being conducted with SFUDS discharges to $80 \%$ DOD. Test results show that all of the $\mathrm{Ni} / \mathrm{MH}$ cells have very low resistance and exceptionally high peak power capability $(-200 \mathrm{~W} / \mathrm{kg}$ at $50 \% \mathrm{DOD})$. The peak. power capability of the $H$-cell is the highest measured at the ADL between -35 and $80 \%$ DOD). A high peak power provides full capacity and maximal vehicle range for all driving profile discharges One cell was removed from life test

$$
\frac{\text { W. H. Deluca }}{\text { Author Name }} \frac{-4 .}{\text { Page }}
$$


after 380 cycles due to a sudden decline in capacity (to $<70 \%$ of its initial 25-An capacity). A reduced cell weight indicated that the capacity decline was due to electrolyte loss. Water (13.6 g) was added to the valve-regulated cell, and full capacity (26.5 Ah) was achieved on a subsequent discharge. Thereafter, the capacity declined at a rate of $-0.5 \mathrm{Ah} /$ cycle. Testing was halted when the capacity declined to 13.8 Ah on cycle 399 . Cell weight was reduced again (by $6.3 \mathrm{~g}$ ). This suggests problems with the integrity of the stainless steel case and/or the pressure release vent. A replacement cell (EV35) was furnished by the manufacturer in April 1992. This cell has a 7-h rating of $35 \mathrm{Ah}$ and will undergo performance and life evaluation.

The second $\mathrm{H}$-cell is still under life test with SFUDS discharges to $80 \%$ DOD (26.3-Wh discharges and 23-Ah $\mathrm{Cl} / \mathrm{Cl}$ charges). This cell has completed $>300$ cycles and retains $\sim 100 \%$ of its initial 28-Ah capacity. The weight of this cell is being periodically measured to identify the onset of any electrolyte losses.

NICKEL/ZINC TECHNOLOGY - Three Ni/Zn cells manufactured by Electrochemica were tested from May 1991 to February 1992. Performance characterization tests were conducted on a 17-Ah cell from May to October 1991. This cell continually exhibited unstable capacity, and its capacity had declined $220 \%$ after 170 cycles (endof-life criterion). Special manufacturerrecommended conditioning cycles were imposed in an attempt to improve cell capacity, but this rejuvenation process was unsuccessful. Testing was halted after the cell had completed 187 cycles, and its capacity had declined to $\sim 40 \%$ of its initial 14.6 Ah.

Performance characterization tests were conducted on two larger cells (60-Ah rating) from August 1991 to February 1992. Testing of the first cell was halted in December 1991 because of excessive heating during an initial charge of $12 \mathrm{~A}$. This occurred after the cell had inadvertently received a $\mathrm{Cl} / \mathrm{CV}$ charge return of $216 \%$ during a $50 \%$ DOD partial discharge test. The cell could be charged (58.5 Ah) at a reduced rate ( $4 \mathrm{~A}$ for $\sim 14.6$ h) without excessive heating, and $-93 \%$ of its initial 53.9 Ah capacity was obtained on discharge. Various conditioning cycles were tried in an attempt to improve the charge acceptance of this cell at increased charge rates, but were not successful. After completing 140 cycles, this cell was removed from testing. The second 60-Ah Ni/Zn cell was tested from December 1991 to February 1992. An abbreviated performance characterization and life test with SFUDS discharges to $80 \%$ DOD were conducted. An initial capacity of 52.3 Ah (110.6 Wh) was achieved with $-112 \%$ charge return. The cell was operated over the December holiday shutdown, during which its capacity increased slightly and the charge return decreased from $\sim 112$ to $105 \%$ (fixed 58.5 -Ah return). In January 1992 , when the charge return was increased from 10.5 to $110 \%$ (manufacturer recommended value), cell capacity increased from $\sim 57$ to 70 An. Because of this large increase in capacity, the abbreviated performance characterization was repeated. The cell then exhibited a specific energy of $66.7 \mathrm{Wh} / \mathrm{kg}$ (3-h rate) and a peak power of $185 \mathrm{~W} / \mathrm{kg}(50 \%$ $D O D)$. The highest $C P$ discharge that could be applied without excessive cell heating was 35 W/kg. Life testing with $80 \%$ DOD SFUDS discharges (75 Wh) and Cl/CV (12 A/1.95 V) charges to $110 \%$ return was started in February 1992 (95 cycles accrued). The cell completed only 20 SFUDS cycles, when the $100 \%$ DOD termination condition (maximum power capability $550 \mathrm{~W} / \mathrm{kg}$ ) was reached before the $80 \%$ DOD energy ( $75 \mathrm{Wh}$ ) could be removed (end-of-life). At that eime, a 3-h rate capacity of $<50$ Ah was obtained, and a thermal runaway condition was starting during the CV portion of the Cl/CV charges. The cell reached end-of-life on cycle 114 and was removed from test in February 1992 after completing 120 cycles. The cells were returned to Electrochemica.

NICKEL/CADMIUM TECHNOLOGY - Life tests are being conducted on a $6-\mathrm{V} \mathrm{Ni/Cd}$ module (190An rating) manufactured by SAFT (Industrial Storage Battery Division), France. The module was received in April 1990 after completing 35 performance characterization cycles at the Idaho National Engineering Laboratory. Life testing was started at the ADL in June 1990 after 78 cycles of performance testing were accrued. Life evaluation is being conducted with $\mathrm{J} 227 \mathrm{aC} / \mathrm{TEV}$ an discharges to $100 \%$ DOD. The module has completed over 900 cycles and retains $-99 \%$ of its initial 214 - Ah (3h rate) capacity. The energy obtained with $100 \%$ DOD TEVan discharges has only declined to $\sim 95 \%$ of its initial $1268 \mathrm{Wh}$. Variations in module resistance, IR-free voltage, and peak power vs. DOD during the life evaluation were examined. Analyses showed that module resistance has increased by $-21 \%$ and IR-free voltage has remained constant to within $0.5 \%$. As a result of 
the increased module resistance, the peak power capability was decreased from 190 to $159 \mathrm{~W} / \mathrm{kg}$ at $50 \%$ DOD $(\sim 16 \%$ decrease $)$ between cycles 46 and 868 . This module is still under life test.

ADVANCED NICKEL/IRON TECHNOLOGY Life tests are being conducted on several advanced Ni/Fe modules (NIF200) from EaglePicher Inclustries, inc. The NIF200 design provides a capacity of 200 Ah in the same module package as the 170-Ah module developed for the dual-shaft electric propulsion (DSEP) vehicle developed by Eaton Corp. Performance characterization tests were completed in early 1990, and three NIF200 modules were placed on life tests. Since that timie, another five NIF200 modules have been placed on life tests. One module, tested from September 1989 to April 1992, completed 918 cycles with G. $V$ an discharges to $80 \%$ DOD before reaching endof-life.

A charging study was conducted to determine an optimal charge regime for the NIF200. ${ }^{2}$ The study evaluated three charge methods: one-step constant current (Cl), two-step constant current ( $\mathrm{Cl} / \mathrm{Cl}$ ), and constant current/constant voltage/constant current (Cl/CV/CI). Also investigated were charge returns (overcharge) of 115 and $135 \%$; constant and pulsed charge currents as the final charge structure with $\mathrm{Cl} / \mathrm{CV} / \mathrm{Cl}$ charging; and a range of overcharge levels to determine the 50\% "charge acceptance point" (i.e., $50 \%$ of charge current used for electrochemical recharge and $50 \%$ used for electrolysis). During these studies, the total outgas volume was measured with each charge regime to indicate charging efficiency. The results of this study showed that charge method and charge current structure had no significant impact on NIF200 module performance. Only the charge return level affected available module capacity and efficiency. At the $50 \%$ charge acceptance point, both efficiency and available capacity were maximal. Hence, ANL recommended a $\mathrm{Cl} / \mathrm{Cl}$ charge regime (for simplicity) and a charge return of $111 \%(50 \%$ charge acceptance point). A life test has been initiated using the ANL. recommended charge regime.

TUBULAR LEAD-ACID TECHNOLOGY - TWO advanced, three-cell, lead-acid modules with tubular positive electrodes (3ET205) made by Chloride EV Systems Ltd. (CEVS), England, were acquired and tested in January 1991. This test measured the 3ET205 cycle life with SFUDS discharges $(100 \% D O D)$ for comparison with that achieved in an EPRI-sponsored test using $\mathrm{J} 227 \mathrm{aC} / \mathrm{G}-\mathrm{V}$ an discharges to $100 \%$ DOD. Both of the new modules underwent an abbreviated performance characterization, and one was selected for life testing with SFUDS discharges. After 149 cycles, this module reached end-of-life ( $<80 \%$ of initial energy). In the EPAI test (1990), the 3ET205 module completed 715 cycles before reaching end-of-life. Post-test analyses revealed that both modules failed due to deterioration of the negative electrodes, caused by high levels of antimony and by poor adhesion between the active materials and the grids. The antimony was generated by corrosion of the positive grids and plated onto the negative electrodes during operation. Charging efficiency and effective capacity of the electrodes were consequently reduced. The cells in the module using SFUDS discharges had a greater divergence in post-test findings than those observed in the EPRI module. Hence, cell mismatch may have impaired the evaluation of the SFUDS test.

RECOMBINANT LEAD-ACID TECHNOLOGY Tests were started in December 1989 for EPRI on two 6-V, valve-regulated lead-acid (VRLA) modules with a gelled electrolyte manufactured by Sonnenschein Battery Co. (Germany). The maintenance-free cells are equipped with pressurerelief valves for gas venting and use an antimonyfree alloy. Both modules completed performance characterization, and one underwent life testing with $\mathrm{J} 227 \mathrm{aC} / \mathrm{G}-\mathrm{V}$ an discharges to $100 \% \mathrm{DOD}$. After 370 cycles, the energy obtained on simulated driving profile discharges had declined to $80 \%$ of its initial level. New modules were delivered from Sonnenschein, and one was placed on life test using G-Van discharges. The module was operated to $100 \%$ DOD for 122 cycles and then changed to $80 \%$ DOD cycling. This module completed 448 cycles before reaching end-of-life (100\% DOD condition reached before the $80 \%$ DOD energy obtained). At that time, the 3-h rate capacity had only declined by $-9 \%$.

\section{FUTURE EVALUATIONS}

In 1992, performance characterization and life evaluations will be continued for DOE/OTT on the $\mathrm{Ni} / \mathrm{MH}$ (Ovonics) $\mathrm{H}$-cells and EV35 cell. Life testing of the $\mathrm{Ni} / \mathrm{Fe}$ (EPI) and $\mathrm{Ni} / \mathrm{Cd}$ (SAFT) modules for EPRI will also be continued. New systems to be evaluated at the ADL in 1992 include full-size $\mathrm{Ni} / \mathrm{MH}$ EV cells from Ovonics, which will undergo

$$
\frac{\text { W. H. Deluca }}{\text { Author Name }} \frac{-6 .}{\text { Page }}
$$


performance and life testing with driving profile discharges. Several Na/S 120-cell modules, which will undergo accelerated life lesting, are also expected.

\section{ACKNOWLEDGMENT}

This work was supported by the Department of Energy, Office of Transportation Systems. Electric and Hybrid Propulsion Division, and the Electric Power Research Institute.

\section{REFERENCES}

1. Performance and Life Evaluation of Advanced Battery Technologies for Electric Vehicle Applications, W. H. Deluca, et al., SAE 1991 Future Transportation Technology Conf., Portland, OR, August 5-8, 1991, SAE Technical Paper 911634 (1991).

2. Effects of Charge Methods and Pulse Charge Currents on Nickel/Iron Traction Battery Performance, W. H. DeLuca, et al., Proc. of the Seventh Annual Battery Conf. on Applications and Advances, Long Beach, CA, January 21-23, 1992, pp. 92EV-7NIII-8.

Table 1. Driving Proflle Characteristlcs

- Driving Schedule

- Vehicle Type

- Battery Weight, kg

- Avg. Speed, mph

- Peak Power, W/kg

- Avg. Power, W/kg

- Energy Consumption, Wh/mile

$\begin{array}{rr}\text { SFUDS } & \text { J227aD } \\ \text { IDSEF } & \text { IETV-1 } \\ 695 & 488 \\ 19.0 & 28.3 \\ 79 & 48 \\ 9.9 & 12.0 \\ 362 & 207\end{array}$

$\mathrm{J} 227 \mathrm{aC}$

G-Van

1180

15.1

36

7.3

570
J227aC

TEVan

839

15.9

29

5.1

269 


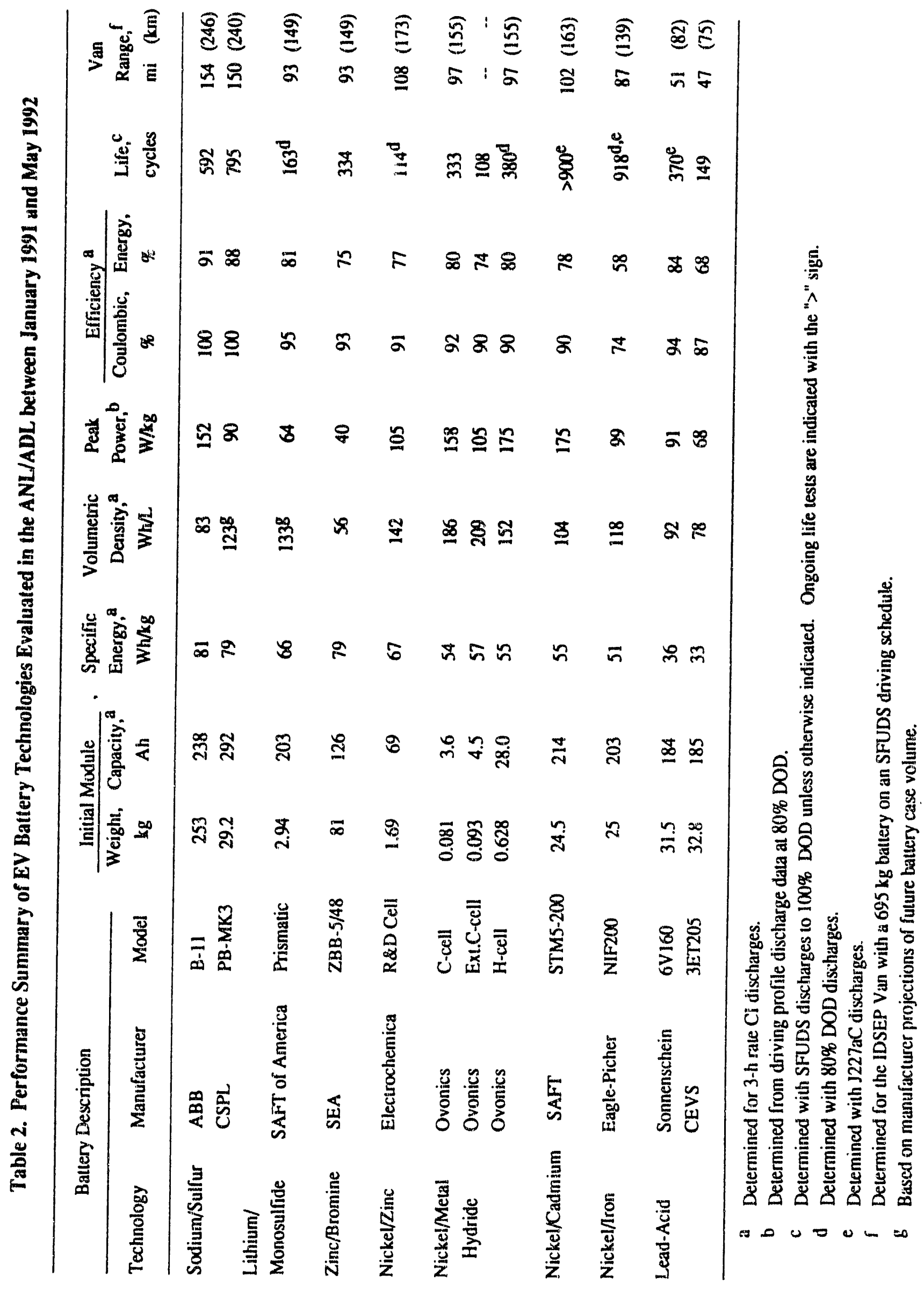




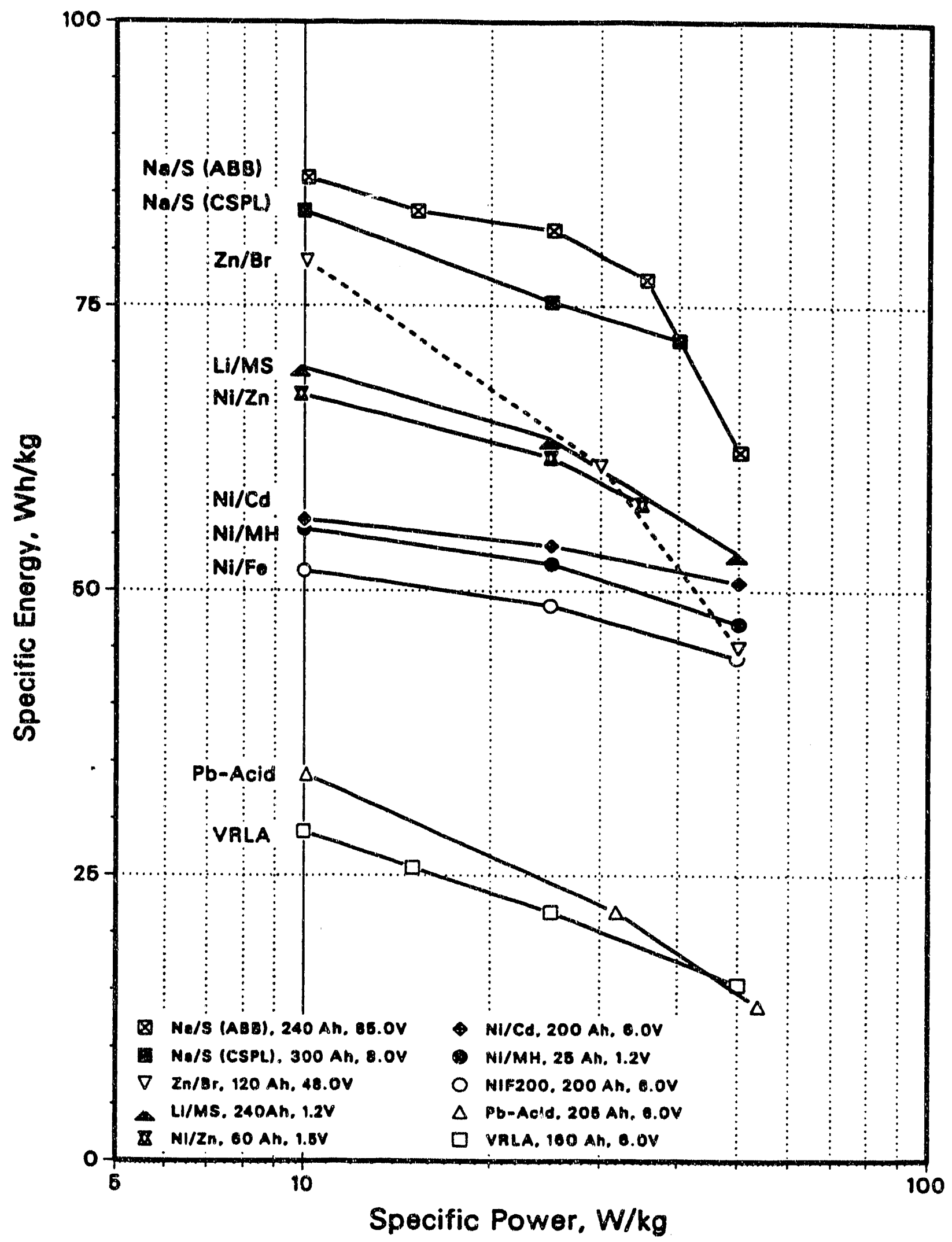

Fig. 1. Effect of discharge specific power on available energy of ten advanced battery technologies. 


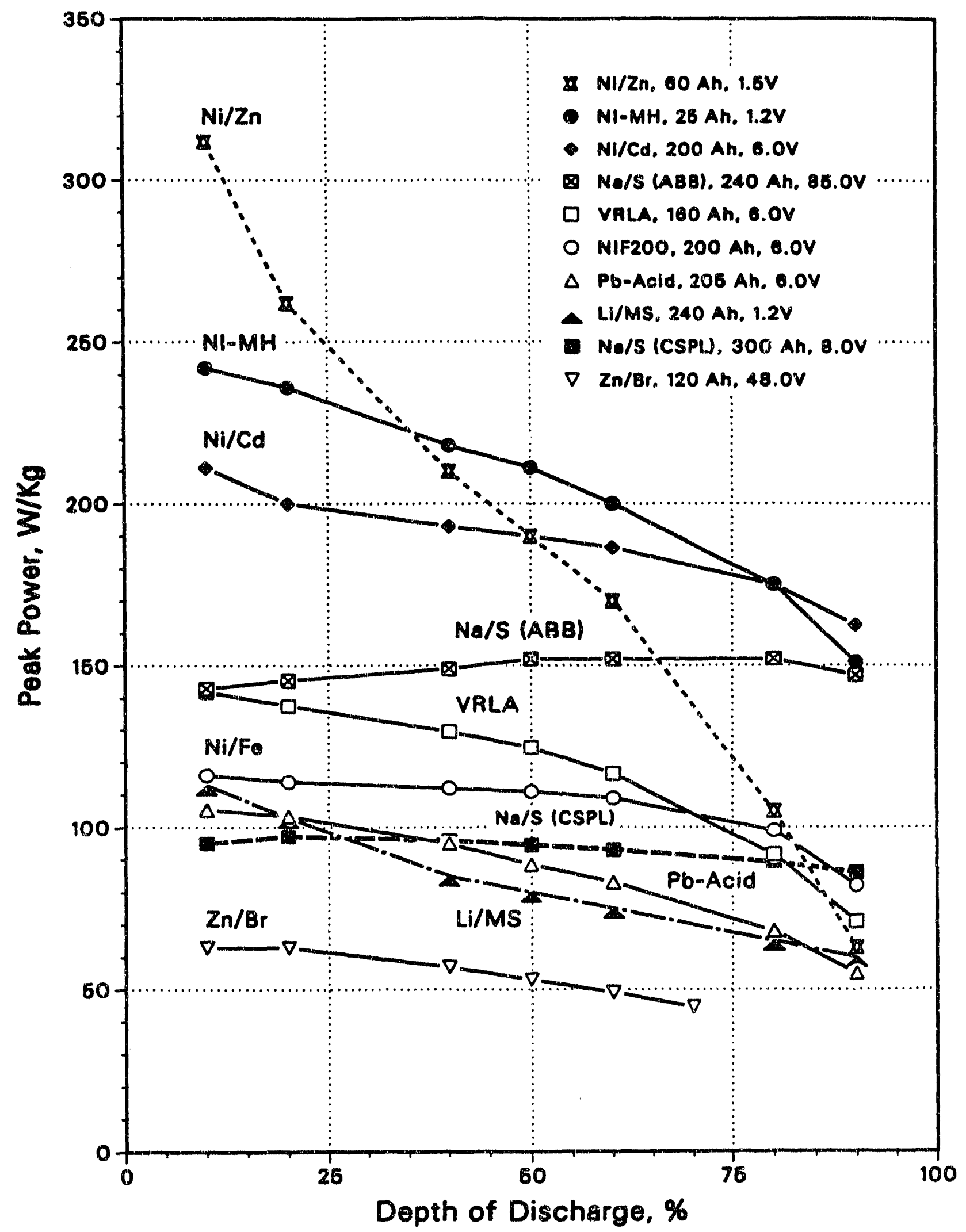

Fig. 2. Derived peak power vs. DOD of ten advanced battery technologies from driving profile discharge (J227aD/IETV1) data. 


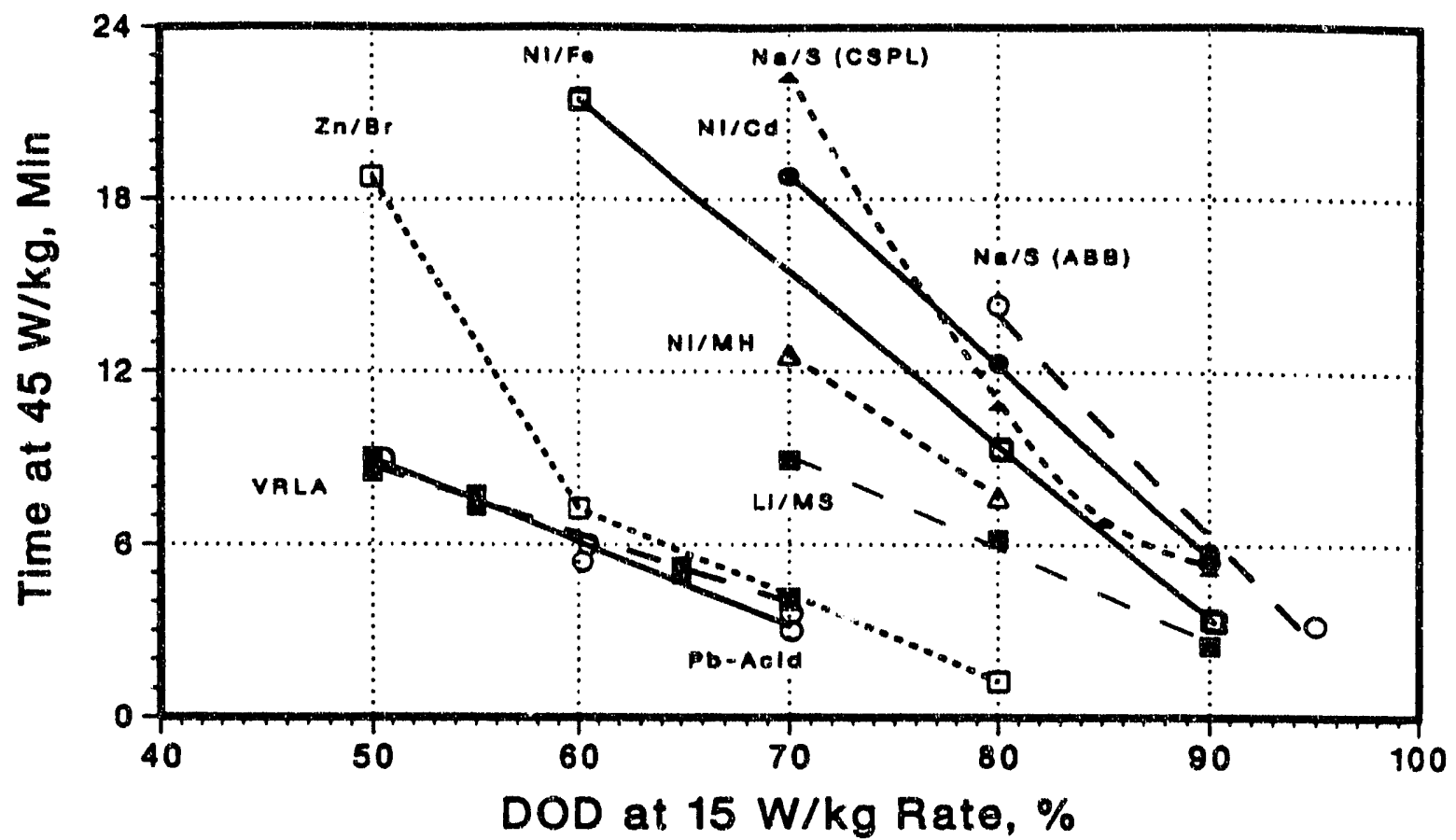

Fig. 3. Time (at $45 \mathrm{~W} / \mathrm{kg}$ ) that electric car (IETV-1) could sustain hill climb (77 grade) at $30 \mathrm{mph}$ as a function of DOD (at $15 \mathrm{~W} / \mathrm{kg}$ rate) for each advanced battery technolony evaluated.

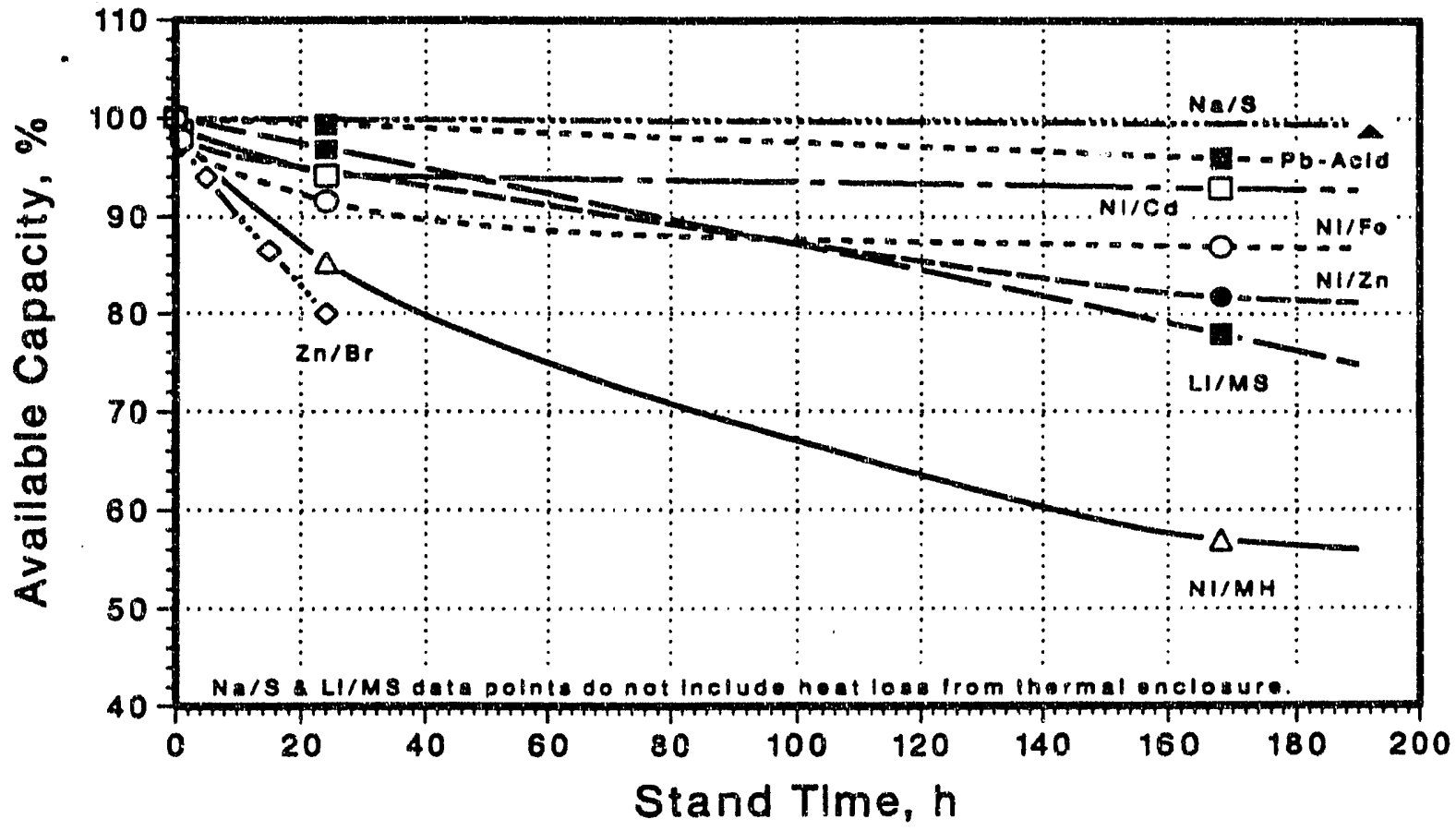

Fig. 4. Available discharge capacity va. open-circuit stand time after charge for each advanced battery technology evahuated. 
$\nabla$
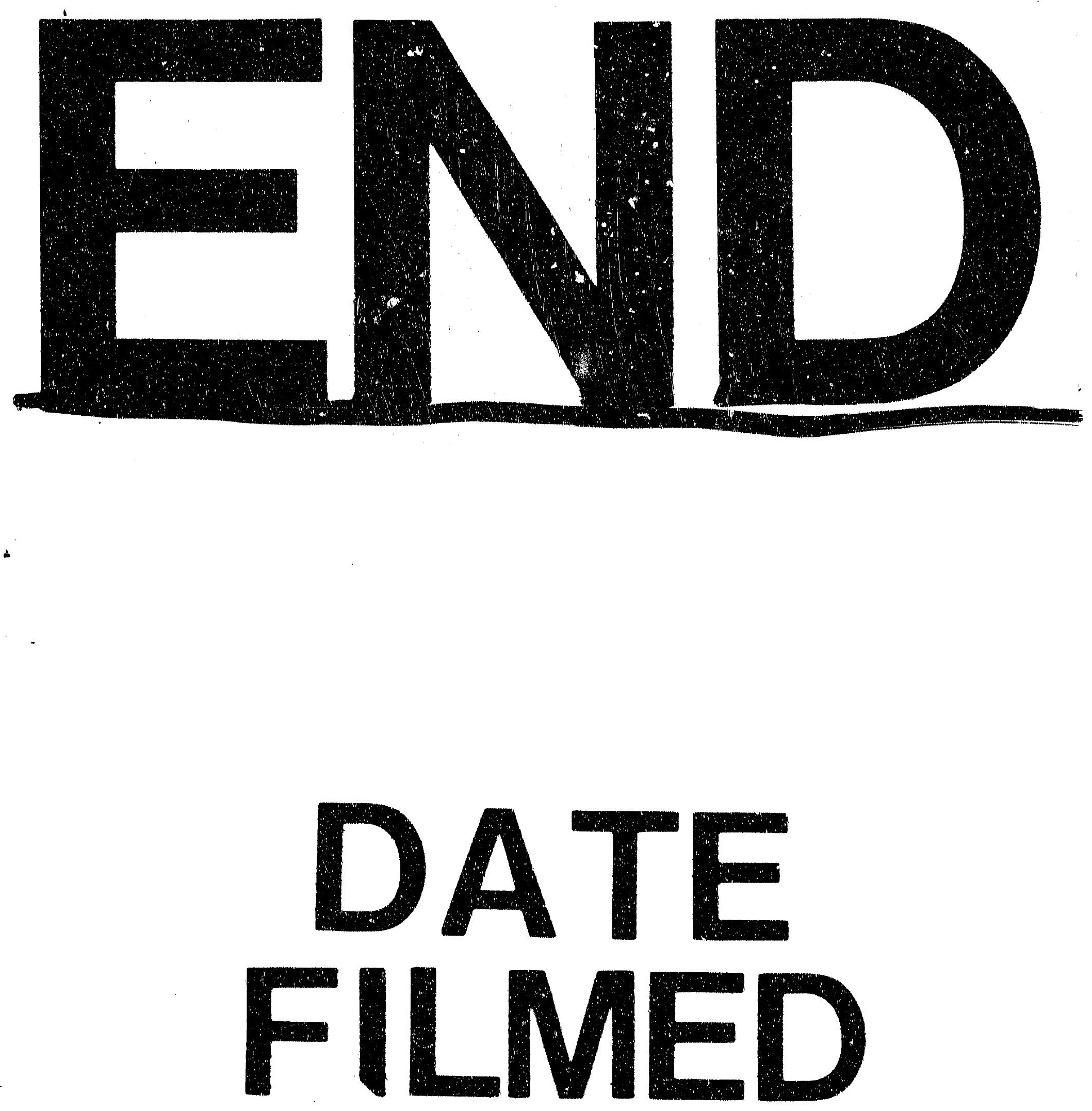

$=$

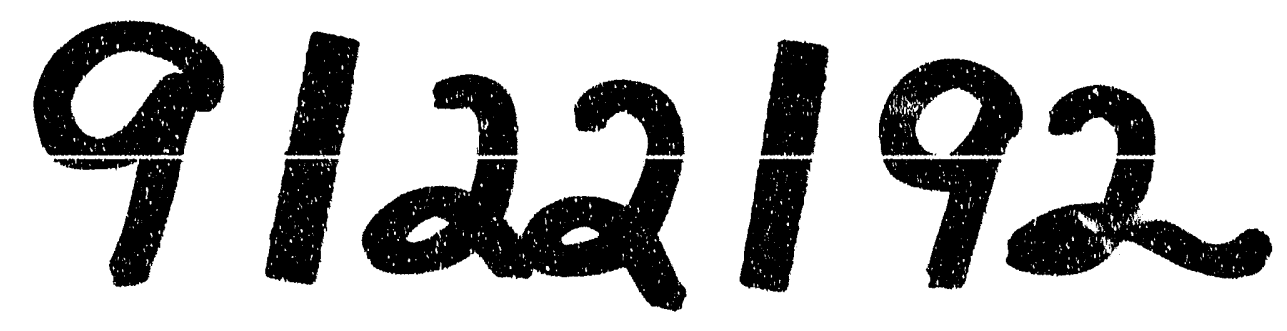


$=$
$=$
$=1$
$=1$
$=1$ 